\title{
Chapter 12 \\ The Influence of Social Capital on the Educational Attainment of Roma Persons: Evidence from a Qualitative Study in Romania
}

\author{
Elena-Loreni Baciu and Theofild-Andrei Lazar
}

\begin{abstract}
As the largest ethnic minority in Europe, Roma persons are among the groups with the lowest levels of educational attainment. In Romania, the country with the highest number of Roma persons of all the EU Members States, the situation is even worse, each higher level of education revealing an increasing gap between Roma persons and the general population.

Positioned within the framework of Social Capital theory, the current chapter explores the influences of micro- and mezzo-level social networks on educational attainment of Roma persons, trying to explain some of the mechanisms that perpetuate the gap between them and the general population, in terms of educational attainment.

Drawing on a qualitative bottom-up study of Roma persons' experiences of belonging in society, we analysed the interlocking influences of bonding and bridging social capital on the interviewees' educational attainment. The results of the study point out that both forms of social capital have an important impact on the educational attainment of persons in vulnerable groups, although in different ways, and sometimes they can be mutually reinforcing, depending on the prevailing social arrangements, in either keeping the persons engaged in education, or drawing them away from their educational paths. The results also show that in circumstances of intersecting vulnerabilities, a noticeable imbalance between agency and structure is
\end{abstract}

\footnotetext{
E.-L. Baciu ( $ه)$

West University of Timisoara, Romania, Social Work Department, Romania and ResearchAction Centre on Discrimination and Social Inclusion, Timişoara, Romania

e-mail: elena.baciu@e-uvt.ro

T.-A. Lazar

Social Work Department, Faculty of Sociology and Psychology, West University of Timişoara, Romania

The Action-Research Center on Discrimination and Social Inclusion (CADIS), Timişoara,

Romania

e-mail: theofild.lazar@e-uvt.ro
} 
produced, which corrodes the foundational principles of equity and affects the equality of opportunities.

Keywords Social capital · Educational attainment · Intersection of economic and social vulnerabilities $\cdot$ Roma persons

\section{Development as an Output of Education}

Based on the human capital theory (Adam Smith), the tight connection between education and development, both at individual and societal level, is globally acknowledged nowadays and stands as one of the main pillars of our social organization system.

The returns of education have been amply discussed, with research exploring both financial and social gains of different levels of educational attainment (see Harmon et al. 2003; Brand 2010; Owens 2004 etc.). At micro-level, educational attainment (EA) has been associated with gainful employment, career development and financial status (see Harmon et al. 2003; Lehmann 2004 etc.). At macro-level, higher levels of education contribute to increased political participation (Mayer 2011; Brand 2010), quality of civic knowledge, support for free speech (Dee 2004) and has positive effects on crime reduction and environment protection (Owens 2004).

Access to education represents one of the fundamental human rights, promoted as such by the Universal Declaration of Human Rights since 1948 and adopted ever since as a major commitment by international institutions and national governments, through a plethora of Charters and Programs (for e.g., The International Education Charter, Students Rights Charter, International Education Week, European Education Area).

However, despite all these large-scale engagements towards the provision of equal access to education for all, there are still many people who continue to have limited access to this basic right. ${ }^{1}$ Investigations into inequalities among different social groups in accessing education show two main categories that face difficulties in advancing their EA: individuals who have low economic resources (see Homel and Ryan 2014; Sirin 2005; Lehmann 2004; Coleman 1988 etc.) and ethnic minorities (see Arouri et al. 2019; Kim and Calzada 2019 etc.). An especially vulnerable position is held by the social groups in which these two different contexts intersect and produce a combined effect of precariousness and marginality, which describes not only the individual or family's situation but also the condition of the communities they reside in and the institutional resources they can access, such as, low quality segregated schools (Council of Europe 2017).

\footnotetext{
${ }^{1}$ World Bank database-School enrollment, primary (\% gross), https://data.worldbank.org/indica tor/SE.PRM.ENRR
} 


\section{Roma, a Group at the Intersection of Multiple Vulnerabilities}

Roma, as the largest ethnic minority in Europe, is among the groups with the lowest levels of EA (O'Hanlon 2016). The latest European survey on minorities, representative for Roma living in nine EU Member States in geographic or administrative units with density of Roma population higher than 10\% (European Union Agency for Fundamental Rights 2016), shows low levels of school attendance and EA among Roma children and clear gaps between them and the general population regarding education, starting with early childhood education, where their participation is only $53 \%$, compared with $87 \%$ among the general population. In terms of school enrolment rates by children age, the survey shows an increasing gap between Roma and the general population with each higher level of education: for primary and lower secondary education (ISCED 1 and 2), 86\% of Roma children are enrolled in the educational level corresponding to their age, compared to $90 \%$ among the general population; for upper secondary education (ISCED 3), 30\% of Roma children are enrolled in the educational level corresponding to their age, compared to $79 \%$ among the general population; while for post-secondary and tertiary education (ISCED 4+), only $2 \%$ of Roma youth are enrolled in the educational level corresponding to their age, compared to $34 \%$ among the general population.

In Romania, the country with the highest Roma population of all EU Members States (1.85 million people according to the Council of Europe, in 2019²), the situation is even worse, with $38 \%$ of Roma children enrolled in kindergarten (compared to $86 \%$ of the general population), $77 \%$ enrolled in ISCED 1 and 2 educational levels (compared to $85 \%$ of the general population), $22 \%$ enrolled in ISCED 3 educational levels (compared to $80 \%$ of the general population), and $77 \%$ of the Roma youth (aged 18-24) registered as early school leavers (compared with only $19 \%$ of the general population) (European Union Agency for Fundamental Rights 2016).

Roma are an ethnic minority, with cultural differences and specific needs that must be taken into account when designing educational inclusion programs (Lauritzen and Nodeland 2018; Tremlett 2014; Walsh and Krieg 2007). Most of them have a low socio-economic status and live in poor neighbourhoods, especially in peripheral rural areas (Berescu 2019; Baciu et al. 2016; Dohotaru et al. 2016). The European Union Agency for Fundamental Rights (2016) notes that, in 2014, around $70 \%$ of the Romanian Roma were at-risk-of-poverty, a percentage significantly higher than in the general population $(25 \%)$. Being at the intersection of economic and social vulnerabilities, the educational well-being of young generations of Roma is negatively influenced and this entails high risks of social exclusion for them (Ravnbøl 2009). Roma community has a growing and predominantly young population in an ageing Europe, and the immediate ending of their current state of intersecting vulnerabilities should represent a top priority for policymakers and

\footnotetext{
${ }^{2}$ https://ec.europa.eu/info/policies/justice-and-fundamental-rights/combatting-discrimination/ roma-and-eu/roma-integration-eu-country/roma-integration-romania_en
} 
program implementers alike. The integration of Roma persons through education has the potential of bringing positive changes on many macro-levels, with a special emphasis on the labour market (World Bank 2010).

\section{A Qualitative Investigation into the Interlocking Influences of Social Capital on the Educational Attainment of Persons from Vulnerable Groups}

There is still an ongoing debate among researchers about which factors contribute more decisively to shaping a person's opportunities and choices when it comes to education. For modelling future policies and programs toward enhancing EA and, thus, improving the returns of education for individuals and societies alike, the results of this debate are extremely important, because they will set out the blueprints for the allocation of resources for such interventions.

The social capital, as a conceptual tool, is strongly embedded into fundamental sociological concepts, and describes a virtuous circle that results from people's shared understanding about values, norms and cooperation (Putnam 1993). As such, and due to the implications it has for the levels of trust, happiness, health and wealth within communities, it has the potential to shape policies and strategies of development (Uslaner and Conley 2003). Its core contribution to social sciences is the portraying of social networks as usable resources or capital, alongside other forms of capital (human, economic, cultural etc.): it helps explain how individuals can gain economic and cultural resources by deliberate socialization within different groups and are thus motivated in creating and developing such networks (Bourdieu 1986). Social capital (SC) has proved to have a great influence on economic development and poverty reduction (Woolcock 2001), but it has also been proven to contribute to reproducing structural patterns of exclusion for economically vulnerable groups (Cleaver 2005; Young 1999). Consequently, given the 'two-sided' nature of SC (Kropf and Newbury-Smith 2016), it is an important task for researchers and policy makers to understand how it works to shape various opportunities for persons from vulnerable groups, and how its two forms (bonding and bridging) interfere with each-other, 'making' or 'breaking' these opportunities.

Positioned within the framework of SC theory (Putnam 2000; Bourdieu 1986; Coleman 1988; Granovetter 1973), the current chapter explores the influences of micro- and mezzo-level social networks on the EA of Roma persons, trying to explain some of the mechanisms that perpetuate the EA gap between Roma persons and the general population. While we acknowledge the importance of the macrolevel policies and programs in supporting inclusive educational climates and increased participation in school for vulnerable groups, we focus our analysis specifically on the mechanisms of the micro- and mezzo-level forces that are at work in shaping the challenges and opportunities of Roma children and youngsters to advance their education. 
A fundamental distinction is made between two forms of SC (bonding and bridging) to try to trace and explain the interlocking influences they have on participants' educational attainment: (1) Bonding SC is the SC developed within closed networks of similar individuals. In general, these include networks composed of family, relatives, and friends (Coleman 1988; Woolcock and Sweetser 2002; Lancee 2010). (2) Bridging SC is conceptualized as the interactions of individuals with networks consisting of persons that are dissimilar to the individual (Woolcock and Sweetser 2002; Field 2003; Lancee 2010), in this case with ethnically and economically diverse entities. The networks formed through interactions with local authorities, local institutions and organizations also fall under this category.

We know, from previous research, that bonding $S C$ is a more common asset among lower income/lower class individuals than bridging $S C$, and that, at the same time, the former is often seen as rather a prerequisite for the development of the latter (Edin and Lein 1997; Sampson 1999; Warren et al. 2001). We also know that, for vulnerable population groups, bonding SC has limited resources to support higher educational attainment (Raymond-Flesch et al. 2017) and that, when available, bridging ties (formed with educational staff_-Ashtiani and Feliciano 2018-and peers with different backgrounds_-Radoš et al. 2019), support vulnerable categories of youngsters to achieve higher levels of EA. However, the empirical evidence about how exactly the two types of capital (bonding and bridging) intertwine in their influencing EA among persons from vulnerable groups is rather scarce, because previous investigations focused mainly on the differences rather than on the synergies between them.

The remainder of the chapter addresses this gap by adding to the body of knowledge about the mechanisms through which the two types of SC shape Roma persons' educational outcomes. In doing so, we try to unpack the complexities of the influences exerted simultaneously by the bonding and bridging capital over Roma persons' educational paths. We pay close attention to the way the balance between individual choice (attributable to agency) and available resources (attributable to structure) is produced in the case of Roma persons' access to education, and if this balance then creates a climate for compliance with the principles of equity and equality of opportunities for all.

\section{Methodology of the Study}

The results presented in what follows are based on a qualitative, bottom up investigation of 24 life stories of Roma individuals from two regions of Romania (the Western and North-Western Regions), collected through a purposeful sampling process, based on the 'information rich' criterion (Patton 2002). The data collection process was part of a larger scale research (see Lazăr et al. 2015 for more details), which explored, from the standpoint of persons from vulnerable groups, how local practices and experiences in the persons' immediate environment are tied into extended social relations or chains of action that organize the 'social happening' 
(Smith 2005; DeVault and McCoy 2006) of belonging in society. The data discussed in the present chapter was collected through individual interviews, based on semistructured interview guides. The central topic that guided the discussion was the interviewees' experiences on the labour market. We used the labour market as an 'entry point' into a set of institutional relations, from where we further explored the ways the 'institutional' (in the sociological sense) order creates the conditions of individual experience. We asked the interviewees to provide in their stories as many details as possible about their experience with schooling, the entities that significantly influenced their educational paths, and the ways they received these influences. Based on the assumption of 'intergenerational transmission of social capital' (Weiss 2012), those interviewees who had children at the time of the interview were asked the same questions about their children as well.

The process of selecting participants (conducted with the support of two regional non-governmental organizations-NGOs_-promoting Roma persons' rights) emphasized variation and, through the purposeful stratification of participants, we intended to ensure different, rather than common profiles of interviewees (Palinkas et al. 2013). As such, we selected 11 men and 13 women, 10 residing in urban areas and 14 in rural areas and 9 employed and 15 unemployed at the time the interviews were conducted. The EA of the interviewees also varies, from the lowest to the highest level of studies: six subjects had no schooling whatsoever, three subjects had started primary school, but didn't finish it, three subjects managed to complete primary school (four grades), two subjects started middle school but didn't finish it, two subjects completed middle school (eight grades), three participants attended high-school without graduating, two participants graduated from high school, and three participants started university, of which only one completed this level. Due to the focus of the investigation, compared to the official statistics on the EA of Roma individuals in Romania, we overrepresented in the sample the number of cases with the lowest level of EA (in order to obtain a comprehensive list of the factors that contribute to school non-attendance and to early school dropout) and those with the highest level of EA (which helped to convey a clear picture of the assets needed by Roma persons to advance on their formal educational path).

\section{Reasons for Not Attending School or for Early School Dropout}

The widespread low EA of Roma persons in Romania (European Union Agency for Fundamental Rights 2016) has been explained by various authors (see Voicu 2007) within the context of their families' lack of financial resources. Despite the fact that mandatory education is free in Romania, families still have to deal with various expenses in order to keep their children in school: buying clothes and shoes, special books or notebooks, supplies, transportation pass, etc. In the case of very poor families, who live on social welfare and daily labour, these expenses can often be unsustainable. 
However, in the stories of the interviewees with no or low levels of EA, the lack of financial resources never appeared as the sole cause for not attending school or dropping out early; it was always mentioned in connection to other reasons, such as dramatic family situations that required them to undertake complex household duties or jobs in order to support and provide for the family.

The need to give up school in order to undertake household duties was often invoked by the female interviewees with no or low EA. Sometimes the household duties involved taking care of siblings, while other times they involved marriage at a young age and moving in with the husband, a change that disrupted the interviewees' educational paths. For example, Denise ${ }^{3}$ (32 years old at the time of the interview) says that she never went to school because she had two smaller brothers she had to care for, while her parents went to work. She comes from a very poor family that struggled to make ends meet, and the parents (without any education at all) always held menial jobs. She started taking on household duties even before she was of school age. Over time, her parents had three more children, so by the time she finished raising her five younger brothers, she got married herself and had her own children to care for. So, she notices, it was never the right moment for her to get an education and her parents were never preoccupied by this aspect. On the other hand, Maria (37 years old at the time of the interview) moved in with her husband shortly after she met him. She was 13 years old and he was 20 . Before that, she lived for 4 years (since the age of 9) in a placement center with her younger sister, due to her mother's serious health issues (her mom was a single parent) and the financial difficulties the family had to face. Although the couple did not have children until Maria was 17, she gave up school as soon as she moved in with her husband, so she finished only five grades. Focused on her and her daughters' survival, Maria's mother had no objections to Maria's dropping out of school.

Dropping out of school due to early involvement in income-providing activities was evoked exclusively by the male interviewees. In such cases, the family's poor economic status or the loss of one income provider (through death, illness or parental separation) constituted the onset for the money earning activities (mostly on the black market) for the youngsters, who had to give up school. Andrew (25 years old at the time of the interview) recalls how he had to start working when he was around 14 years old, due to his father's untimely death. His mother (who had no education at all) was left to care for her four children, which was impossible due to her small income obtained from temporary and precarious employment. As a result, the oldest male child (Andrew) had to get involved in providing an income for the family.

The outcomes of not attending or dropping out of school at a young age were strongly felt as negative by all the interviewees concerned, especially in the area of labour market integration: the unemployed felt that their chances to find a job would have been significantly enhanced if they had completed a higher level of education, while those who had secured a job felt their low EA impeded their professional advancement, despite the fact that they had the job experience and the skills needed

\footnotetext{
${ }^{3}$ The names are invented, in order to protect the identity of the interviewees.
} 
for a higher position. Other interviewees expressed regret at not enrolling in school or giving it up too soon, because they faced difficulties in their day-to-day life even in small activities like reading, filling out a form or understanding complex ideas expressed in the news, TV shows or movies.

All the interviewees with low EA who had children expressed, in some way or another, their desire for their children to be better educated than them, although their projections for their children's educational paths varied. For example, Denise, the 32 year old who never went to school because she had to care for her five siblings, has difficulties imagining her two children (one in the first grade and the other in the fifth) going beyond eighth grade, because a middle school is the highest education institution available in the small rural community where they live. In order to access further schooling, the children would have to travel outside the rural community, a scenario that seems implausible to Denise at this stage. Maria, however (the girl who moved with her future husband at 13 and dropped out of school after fifth grade), has great ambitions for her three children: her eldest daughter (aged 20) is enrolled in Law school at the University in the city where they live, and her middle daughter attends the Pedagogical High school in the same city (one of the most prestigious high schools in town). The youngest child, a 9 year old boy who is now in middle school, takes private lessons in order to make sure he will be admitted the same high school in ninth grade. Maria says she doesn't expect him to help around the house as long as he does well in school.

\section{Assets Needed to Advance on the Formal Educational Path}

The interviewees with high EA mentioned the influence of their parents' attitudes and opinions regarding education as definitive in motivating them to stay in school: the parental figures were the ones that provided them the support, encouragement and sometimes even the coercion necessary to keep them engaged in education. In most cases, the supportive parents were located in urban areas or had at least an average financial status.

Daniel (47 years old at the time of the interview) comes from a traditional Roma family with seven children, who lived in a rural community and had a small farm. By the time he was 7 years old, both his parents had died, so he was left in the care of his six older brothers. One of his (Romanian) neighbours, somewhat wealthy, took him in, initially wanting to adopt him. Because some legal complications appeared in the process, the adoption did not go through. However, for the rest of his youth, the neighbour took responsibility for him and acted as a parental figure. He supported him all the way through middle school and high school. He remembers the expenses to keep him in high school were quite high, because he had to move to the city during the school year. Looking back on his childhood and youth, Daniel acknowledges that the care and support received from his neighbour were much higher than his parents could have provided him if they had been alive at that time. 
Peter, on the other hand ( 24 years old at the time of the interview), does not hesitate to mention that, although he wasn't too fond of school, he had no other choice but to finish high school, because his parents did not allow him to drop out. He later started university twice (in two different programs), but dropped out each time before the end of the first year. He describes his family as "non-traditional Roma, for sure". Also, his fiancée is Romanian and he has a lot of friends outside the Roma community.

Another important factor mentioned by the interviewees was the institutionalized support programs provided to Roma persons to continue their education. For example, all three subjects that enrolled in University programs mentioned they accessed the national Roma university scholarships program. ${ }^{4}$ Additionally, women interviewees with low education level, from both urban and rural areas, completed primary school or learned to read and write after enrolling in special programs, such as the Second Chance program. ${ }^{5}$

Annie (44 years old at the time of the interview) says that, when she was a child, there was a clear distinction between boys and girls, when it came to Roma parents' expectations about their children's educational attainment: the parents expected their girls to end their educational path once they had learned to read and write. So, she quit school after she completed the eighth grade, which was an unusually high level of studies for a girl in her traditional community and, she confesses, made her parents seem quite "liberal" at the time among the community members. It was only when she turned 40 that she decided to resume her education, so she enrolled in a support program for Roma women and completed eleven grades.

In their stories about their educational paths, the interviewees mention various types of institutional interventions that they experienced and considered useful in promoting education for Roma persons:

(a) At a local level: clothing and school supplies aid from the local budget; recruitment of the school age children by the school educators and teachers directly from the community, through house calls;

(b) At a national level: the Second Chance program; the university scholarships for Roma program; the mandatory enrolment of children in kindergarten for at least 1 year, before enrolling them in the first grade; 10 years of mandatory school; the conditioning of the state allowance for children on the children's enrolment and participation in school; the "Bread-roll and milk" program"; the school mediators;

(c) At a European level: intervention programs implemented by local NGOs, with EU funding, enhancing access to basic education, or providing training programs for educators and teachers on managing diversity in the classroom. Most

\footnotetext{
${ }^{4}$ A government-sponsored program which provides university scholarships for Roma students.

${ }^{5} \mathrm{~A}$ school program which allows persons (adults) with no or low levels of education to re-enroll in school and graduate the primary and/or lower secondary level (ISCED 1 or 2).

${ }^{6} \mathrm{~A}$ government-sponsored program through which a light lunch (one bread-roll and an yogurt, usually) is provided in schools, for children from poor families.
} 
often, the interviewees, especially those from rural areas, were acquainted with such support programs thanks to the help and mediation of NGOs, which brought information into communities, and supported and motivated the individuals in the process of completing their education.

Since high EA among Roma persons is such a rare asset, the interviewees who had this asset were also quite proud of it and of themselves. They were aware they had managed to do something that is very uncommon among their peers. Daniel (the orphan who was supported by his neighbour) confesses that, when he returned to his parents' village after graduating from high school, he and his quasi-adoptive parents were extremely proud about it because he was 'the first gypsy with a baccalaureate ${ }^{7}$ degree in the whole village'. Annie, the woman who resumed her education at 40 , was a source of inspiration for other middle-aged women in her community, who also decided to join her in the program. She mentioned that the oldest neighbour that became her school colleague was 48 years old at the time.

The interviewees with higher EA also mentioned they needed a lot of determination and courage in order to overcome the many obstacles they encountered on their educational paths. One of these obstacles consisted of the discrimination experienced in the educational environment. Discriminatory attitudes and behaviours during the schooling period were pointed out by almost all interviewees, regardless of their gender, where they lived or the period when they went to school. Name calling ('gipsy', 'crow') and social isolation by peers were some of the most frequent forms of discrimination experienced by the interviewees, together with teachers treating them in ways that felt unfair at the time.

\section{An Overview of the Interviewees' Social Capital}

Building on Bram Lancee's (2010) approach to assessing SC, we analysed two dimensions-structural and cognitive-for both bonding and bridging SC. Structural bonding SC is understood as the strength of family ties and cognitive bonding $S C$ is understood as attitudes and values (including particularized trust) that contribute to the exchange of resources in close and dense networks. In contrast, structural bridging $S C$ is represented by the collection of ties that forms one's extended social network, while cognitive bridging $S C$ is seen as the attitudes and values (including thin or generalized trust and outward orientation) that contribute to the exchange of resources in wide social networks.

The type of SC that appears most visibly throughout the stories of all interviewees is the bonding SC. The analysis of the structure of the bonding SC showed that the interviewees' closest, densest and strongest ties had been with the members of their family and the co-ethnics in their community. This confirms previous observations

\footnotetext{
${ }^{7}$ High school degree.
} 
that the family social network is the most accessible and most used form of SC (Coleman 1988): all participants, regardless of their EA level, placed a lot of emphasis on the pivotal role and function of family (parents and siblings alike) in their daily life and in their decisions-making process about major aspects such as education, marriage and employment. Additionally, the interviewees also evoked enhanced involvement, collaboration and exchange with ethnic community members, especially those living in extreme poverty or residing in segregated communities. The existence of stronger co-ethnic ties (ethnic solidarity) in contexts involving minorities, poverty or marginalization have been previously discussed (Lancee 2010; Sanders 2002) and attributed to the need of the members of such communities to protect and support each other, acknowledging the fact that they would not manage on their own, individually. The interaction between members of these communities is frequent and intense and, in some cases represents an extension of the family network, with neighbours sharing limited resources (for e.g., clean water) or "borrowing" 8 " various things from one another (for e.g., electricity, TV cable etc.). Based on these patterns of interaction, a further analysis of the cognitive dimension of the bonding $S C$ revealed a diffusion of similar attitudes and values among members of the same community. The more segregated the community, the higher the agreement among its members about what is necessary, acceptable, or desirable. Unavoidably, these values were absorbed within the family and further disseminated by parents to their children. The trust between the members of these communities is particularized (they trust only each other) with shared practices supporting a collectivist model and with a clear division between "us" and "them", along the lines of ethnicity. As such, during the discourse analysis phase, we noticed in the interviewees" stories that the first-person statements were mainly in plural ("we, the people living here are poor", "we, the Roma from the gipsy world", "the people in the Town Hall built us houses"), even when the storyteller was not directly involved in the particular experience that was reported.

The interviewees' reports about what ultimately constitutes their SC that bridged the ethnic divide converged to produce an image of marginality and powerlessness, where acceptance and integration in the society relied heavily on the benevolence of the non-Roma majority. In terms of structure, the interviewees' bridging SC depended mainly on a number of factors that configured, on the one hand, the person's status within the society, but, on the other hand and more importantly, the welfare of the community/neighbourhood they lived in. For those living in poor and marginalized communities, the interactions with other ethnic groups was limited, episodic, and purposeful. Mostly, it involved formal encounters with various local public institutions (municipality, school, labour market office, hospital, etc.), prompted by the necessity to either fulfil a specific need (when the encounter was sought by the persons), or solve a legal issue (when the encounter was initiated by

\footnotetext{
${ }^{8}$ Although illegal, borrowing is a widespread practice in poor neighborhoods, where an unsecure connection between two or more households allows them to share electricity or cable with each other.
} 
the institution). The stories of the interviewees residing in segregated communities showed that local NGOs are an important source of support in facilitating bridging interactions with public institutions and often act as Roma persons' advocates in such encounters. Furthermore, the analysis of the discourse used by the interviewees residing in segregated communities showed a certain degree of institutional blindness among them (characterized by a low level of awareness about formal institutional details, such as the name of institutions they accessed, or the type of services they received), coupled with the instrumentalization of such institutions (characterized by the person's representation of a certain institution only in terms of the benefits or services received from it-the Town Hall is represented by the "social benefits", the Employment Office is equalled with "unemployment benefits" etc.). Interviewees evoked names of professionals that provided them support or assistance, but were unable to name the institutions those professionals worked for. For example, when an interviewee mentioned that she "received the social (i.e., welfare) from Mrs. Claudia", she expressed in fact that the Town Hall was providing her and her family with social benefits and the social worker (in the person of Mrs. Claudia) was the person from this institution that managed the case. Such a representation, 'stuck in informality' (Breimo and Baciu 2016), distorts, for the persons concerned, the understanding of the legal arrangements behind the provision of support, making it seem discretionary and depending on the benevolence of the donor identified by name. For the beneficiary receiving the support, it is not a matter of their legal rights, but a matter of the good will of the provider.

On the other hand, the interviewees living in more resourceful communities were more aware of the institutional resources available to them and also had more frequent contact with persons from diverse ethnic backgrounds.

The cognitive dimension of the interviewees' bridging $S C$ also varied with the social and economic conditions characterising the community/neighbourhood the persons lived in. For those interviewees residing in poor and segregated communities, their narratives showed a low level of trust in persons from outside the community, apart from those they had already interacted with and the interaction had proven successful and beneficial. Interaction with non-Roma persons, which have no prior proven benefit, are not necessarily unwelcomed, but they are neither sought for, nor invested with trust. The interviewees residing in mixed non-poor communities have a different pattern of interaction and socialization with non-Roma, being involved in various cross-ethnic networks (in school, at work, in their spare time), whose members they invest with trust and whose opinion they value.

\section{Conclusions: The Influence of Social Capital on Educational Attainment of Persons from Vulnerable Groups}

When placing under scrutiny together the EA level and the $S C$ of the interviewees, the first thing we notice is that the low levels of EA were prevalent among the interviewees who had access to narrow social networks. An examination of the 
mechanisms that link these two dimensions (low EA and limited bridging SC) reveals some aspects that are present and readily observable and others that are significant through their absence.

Poverty, precarity and marginality are among the aspects from the first category, and are vividly evoked by the interviewees in their stories, thus becoming the main descriptors that paint the picture of the interviewees' childhoods: poor family, deprived community, reduced socialization opportunities outside the community, daily struggles to make ends meet. Under the circumstances, the consequence is a somewhat natural prioritisation of efforts based on the benefits they provide, and, for parents, children's schooling is put on the back burner, surpassed by activities that provide more immediate and concrete returns (household duties, income provision activities). Since the model of low or even no school attendance is generalized among the members of the community, no one in the neighbourhood is alarmed or even disturbed when a child is not enrolled in school or drops out. These are the (visible) influences of (what essentially constituted) the interviewees' bonding SC on their school participation.

The bridging SC, however, is notable through its very absence from this picture: when they dropped out, the interviewees and their families held no significant connections to the 'outside' world, and had no alternative models from what was already familiar to them within the community (low school levels or no school at all). Moreover, no institutional bridge (over the ethnic gap) was available either, meaning that no relevant institutions from the community (like the school or the local municipality) made inquiries about the child's whereabouts, in the context of his/her school non-attendance or dropout.

Thus, because of the precarious situation of their families and communities, these persons were deprived of what should have been the resources generally associated with their bonding SC: supervision, monitoring, motivation and financial support from the family (Roksa and Kinsley 2018; Weiss 2012; Garg et al. 2002; Fan and Chen 2001; Muller 2018), in order to begin or advance their education. Moreover, the institutional actors from the community, associated with what could have been their bridging SC, did not step in to compensate or replace these losses at the proper time. From the interviewees' stories, it is clear that the relevant institutions (municipality, school) did nothing about their school non-attendance or dropout.

So, for these interviewees' educational path, the influence of their social capital, in both its forms, had centrifugal effects, derailing them from it, but for different reasons: the bonding $\mathrm{SC}$ had nothing usable to provide in order to keep the (then) child on track, while what should have been the bridging SC was partially or entirely absent (at least for the child) at the time. Thus, for the interviewees in this situation, we can barely say they were 'actors' in their settings, since, due to their young ages, they had no real choice to make about their education, but their paths were rather laid out in front of them by the social arrangements they and their families were caught in.

Conversely, when looking at the stories of the interviewees who 'made it', we notice that the highest levels of EA were prevalent among those interviewees who could rely on their bonding SC and who, in one way or another, accessed social 
networks that bridged the ethnic divide. On the one hand, their bonding SC acted like a resource, through modelling their educational aspirations, supporting them in making the 'smart choices' and motivating them to stay in school; all these family inputs have been already proved as essential for children's EA (Homel and Ryan 2014; Garg et al. 2002; Fan and Chen 2001).

On the other hand, the bridging SC also acted as a useful resource, mediating the persons' access to financial support (for e.g., scholarships), information (NGOs), educational programs, and exposure to positive models. These examples confirm the already formulated necessity of 'institutional backing' (Lamas et al. 2018) within the community structure in order to enhance EA of young Roma students. It becomes clear that, when institutional actors decide to do something about it, there can be noticeable improvements in the EA of persons from vulnerable groups.

In their cases, both forms of SC had a centripetal effect towards their EA, keeping them in school through modelling their expectations and providing them with, or at least mediating their access to the necessary resources for advancing their education.

However, as the narratives showed, their exposure to inter-ethnic socialization was not necessarily premeditated in some way, but rather decided externally and either presented by the interviewees as a 'given' (in the case of those residing in heterogeneous non-poor neighbourhoods), or perceived as a 'lucky opportunity' offered by fate (like in the case of Daniel, the orphan 'adopted' by the Romanian neighbour). Again, the 'agency' of the interviewees was superseded by the structures that surrounded them. Such structures are not necessarily produced locally, via current social and institutional arrangements, but are rather the reflections of old and widely entrenched negative stereotypes and representations about Roma ethnicity, circulated in Romania (Lazăr et al. 2015), but also in the larger European space (McGarry 2012).

Turning to the interviewees' narratives about their own children's educational projections we notice an improvement compared to their own situations, although more for those in non-poor and non-segregated communities. These micro-level improvements, combined with the recent mezzo-level institutional progress (involvement of the NGO sector, availability of institutionalized support programs, de-segregation of schools, prohibition of discrimination), hold the potential to generate positive changes in the long run.

Seeking to understand how the SC works to shape various opportunities for persons from vulnerable groups, the current chapter has discussed the mechanisms through which the bonding and bridging SC influences the EA of Roma persons. The 24 stories of educational success and failure of our Roma interviewees allowed us to glance at the important but different roles each form of SC has. We have, thus, noticed that, when they are available, the two forms of SC can have a mutually reinforcing effect, drawing the persons towards their educational path and keeping them there. We have also observed that, for those persons that found themselves at the intersection of economic and social vulnerabilities (which is the case for most Roma persons), the SC, in both its forms, has an opposite, although still mutually reinforcing effect, distancing the persons from their educational paths. 
Furthermore, we have noticed throughout our interviewees' narratives a clear imbalance between structure and agency when it came to their choices or opportunities regarding their own educational paths: the replication of the 'success stories' is hardly possible at the individual level, because they very much depended on fortunate contexts. As it can be observed from the gaps accumulated between the EA levels of Roma persons and those of the general population, such an imbalance corrodes in time the foundational principles of equity and undermines the equality of opportunities.

If a decrease of the EA gap of the persons in vulnerable situations is desired, then local and central institutional actors alike need to step in and do something about itin terms of providing support programs that can enrich both forms of SC, in order to help individuals to take control over their own educational paths.

\section{References}

Arouri, M., Ben-Youssef, A., \& Nguyen, C. V. (2019). Ethnic and racial disparities in children's education: Comparative evidence from Ethiopia, India, Peru and Vietnam. Children and Youth Services Review, 100, 503-514.

Ashtiani, M., \& Feliciano, C. (2018). Access and mobilization: How social capital relates to low-income youth's postsecondary educational (PSE) attainment. Youth \& Society, 50(4), 439-461.

Baciu, E. L., Dinca, M., Lazar, T., \& Sandvin, J. T. (2016). Exploring the social relations of Roma employability: The case of rural segregated communities in Romania. Journal of Comparative Social Work, 11(1), 1-30.

Berescu, C. (2019). How many ghettos can we count? Identifying Roma neighbourhoods in Romanian municipalities. In E. Vincze, N. Petrovici, C. Raț, \& G. Picker (Eds.), Racialized labour in Romania. Neighborhoods, communities, and urban marginality (pp. 179-205). Cham: Palgrave Macmillan.

Bourdieu, P. (1986). The forms of capital. In J. Richardson (Ed.), Handbook of theory of research for the sociology of education (pp. 241-258). New York: Greenwood Press.

Brand, J. E. (2010). Civic returns to higher education: A note on heterogeneous effects. Social Forces, 89(2), 417-434.

Breimo, I. P. J., \& Baciu, E. L. (2016). Romanian Roma: An institutional ethnography of labour market exclusion. Social Inclusion, 4(1), 116-126.

Cleaver, F. (2005). The inequality of social capital and the reproduction of chronic poverty. World Development, 33(6), 893-906.

Coleman, J. S. (1988). Social capital in the creation of human capital. American Journal of Sociology, 94, S95-S120.

Council of Europe. (2017). Fighting school segregation in Europe through inclusive education: A position paper. Council of Europe. SPDP.

Dee, T. S. (2004). Are there civic returns to education? Journal of Public Economics, 88(9-10), 1697-1720

DeVault, M., \& McCoy, L. (2006). Institutional ethnography: Using interviews to investigate ruling relations. In D. E. Smith (Ed.), Institutional ethnography as practice (pp. 15-34). Lanham, MD: Rowman \& Littlefield.

Dohotaru, A., Harbula, H., \& Vincze, E. (2016). Pata. Cluj Napoca: Efes.

Edin, K., \& Lein, L. (1997). Making ends meet. New York: Russell Sage Foundation.

European Union Agency for Fundamental Rights. (2016). Second European Union Minorities and Discrimination Survey (EU-MIDIS II). Roma-Selected findings. Luxembourg: Publications Office of the European Union. 
Fan, X., \& Chen, M. (2001). Parental involvement and students' academic achievement: A metaanalysis. Educational Psychology Review, 13(1), 1-22.

Field, J. (2003). Social capital. London: Routledge.

Garg, R., Kauppi, C., Lewko, J., \& Urajnik, D. (2002). A structural model of educational aspirations. Journal of Career Development, 29(2), 87-108.

Granovetter, M. S. (1973). The strength of weak ties. American Journal of Sociology, 78(6), $1360-1380$.

Harmon, C., Oosterbeek, H., \& Walker, I. (2003). The returns to education: Microeconomics. Journal of Economic Surveys, 17(2), 115-155.

Homel, J., \& Ryan, C. (2014). Educational outcomes: The impact of aspirations and the role of student background characteristics. Adelaide: NCVER.

Kim, Y., \& Calzada, E. J. (2019). Skin color and academic achievement in young, Latino children: Impacts across gender and ethnic group. Cultural Diversity and Ethnic Minority Psychology, 25 (2), 220-231.

Kropf, A., \& Newbury-Smith, T. C. (2016). Wasta as a form of social capital? an institutional perspective. In M. A. Ramady (Ed.) The political economy of Wasta: Use and abuse of social capital networking (pp. 3-22). Cham: Springer.

Lamas, M., Sànchez-Busqués, S., \& Lalueza, J. L. (2018). Changes in school through a long-term project of action research. Building bridges between school practice and Roma communities. Educational Action Research, 1-16.

Lancee, B. (2010). The economic returns of immigrants' bonding and bridging social capital: The case of the Netherlands. International Migration Review, 44(1), 202-226.

Lauritzen, S. M., \& Nodeland, T. S. (2018). "What is the problem represented to be?" Two decades of research on Roma and education in Europe. Educational Research Review, 24, 148-169.

Lazăr, T.A., Dincă, M., Ungureanu, R., Sandvin, J., Breimo Paulsen, J., Fyling, I., Alexiu, T. M., Baciu, E. L. \& Bîrneanu, A. (2015). Investigating the institutional relations and structural mechanisms underpinning the hindrances and barriers to employment experienced by Roma individuals in Romania. Research report. Retrieved from www.e-qual-see.ro/?page_id=628

Lehmann, W. (2004). "For some reason, I get a little scared": Structure, agency, and risk in schoolwork transitions. Journal of Youth Studies, 7(4), 379-396.

Mayer, A. K. (2011). Does education increase political participation? The Journal of Politics, 73(3), 633-645.

McGarry, A. (2012). The dilemma of the European Union's Roma policy. Critical Social Policy, 32 (1), 126-136.

Muller, C. (2018). Parent involvement and academic achievement: An analysis of family resources available to the child. Parents, Their Children, and Schools, 77-114.

O'Hanlon, C. (2016). The European struggle to educate and include Roma people: A critique of differences in policy and practice in Western and Eastern EU countries. Social Inclusion, 8(1), $1-10$.

Owens, J. (2004). A review of the social and nonmarket returns to education. Wales, UK: Education and Learning.

Palinkas, L. A., Horwitz, S. M., Green, C. A., Wisdom, J. P., Duan, N., \& Hoagwood, K. (2013). Purposeful sampling for qualitative data collection and analysis in mixed method implementation research. Administration and Policy in Mental Health and Mental Health Services Research, 42(5), 533-544.

Patton, M. Q. (2002). Qualitative research and evaluation methods (3rd edn). Thousand Oaks, CA: Sage.

Putnam, R. D. (1993). Making democracy work: Civic traditions in modern Italy. Princeton: Princeton University Press.

Putnam, R. D. (2000). Bowling alone: The collapse and revival of American community. New York: Simon \& Schuster.

Radoš, S., Zdraveva, M., \& Žeželj, I. (2019). Status dynamics in the classroom: Roma children's implicit and explicit preference for majority children across age groups. Journal of CrossCultural Psychology, 50(4), 577-593. 
Ravnbøl, C. I. (2009). Intersectional discrimination against children: Discrimination against Romani children and anti-discrimination measures to address child trafficking. UNICEF Innocenti Research Centre.

Raymond-Flesch, M., Auerswald, C., McGlone, L., Comfort, M., \& Minnis, A. (2017). Building social capital to promote adolescent wellbeing: A qualitative study with teens in a Latino agricultural community. BMC Public Health, 17(1), 177.

Roksa, J., \& Kinsley, P. (2018). The role of family support in facilitating academic success of low-income students. Research in Higher Education, 60(1), 1-22.

Sampson, R. J. (1999). What "community" supplies. In R. F. Ferguson \& W. T. Dickens (Eds.), Urban problems and community redevelopment (pp. 241-292). Washington, DC: Brookings Institution.

Sanders, J. (2002). Ethnic boundaries and identity in plural societies. Annual Review of Sociology, $28,327-357$.

Sirin, S. R. (2005). Socioeconomic status and academic achievement: A meta-analytic review of research. Review of Educational Research, 75(3), 417-453.

Smith, D. E. (2005). Institutional ethnography. A sociology for people. Toronto: Altamira Press.

Tremlett, A. (2014). Making a difference without creating a difference: Super-diversity as a new direction for research on Roma minorities. Ethnicities, 14(6), 830-848.

Uslaner, E., \& Conley, R. S. (2003). Civic engagement and particularized trust: The ties that bind people to their ethnic communities. American Politics Research, 31(4), 331-360.

Voicu, M. (2007). Nevoi şi resurse în comunitățile de romi [Needs and resources in Roma communities]. București: Fundația Soros România.

Walsh, C., \& Krieg, B. (2007). Roma identity: Contrasting constructions. Canadian Ethnic Studies, 39(1-2), 169-186.

Warren, M. R., Thompson, J. P., \& Saegert, S. (2001). The role of social capital in combating poverty. In S. Saegert, J. P. Thompson, \& M. R. Warren (Eds.), Social capital and poor communities (pp. 1-28). New York: Russell Sage.

Weiss, H. E. (2012). The intergenerational transmission of social capital: A developmental approach to adolescent social capital formation. Sociological Inquiry, 82(2), 212-235.

Woolcock, M. (2001). The place of social capital in understanding social and economic outcomes. Canadian Journal of Policy Research, 2(1), 11-17.

Woolcock, M., \& Sweetser, A. T. (2002). Bright ideas: Social capital—the bonds that connect. ADB Review, 34(2), 26-27.

World Bank. (2010). Economic costs of Roma exclusion. Washington, DC: World Bank.

Young, A. (1999). The (non)accumulation of capital: Explicating the relationship of structure and agency in the lives of poor black men. Sociological Theory, 17(2), 201-227.

Open Access This chapter is licensed under the terms of the Creative Commons Attribution 4.0 International License (http://creativecommons.org/licenses/by/4.0/), which permits use, sharing, adaptation, distribution and reproduction in any medium or format, as long as you give appropriate credit to the original author(s) and the source, provide a link to the Creative Commons licence and indicate if changes were made.

The images or other third party material in this chapter are included in the chapter's Creative Commons licence, unless indicated otherwise in a credit line to the material. If material is not included in the chapter's Creative Commons licence and your intended use is not permitted by statutory regulation or exceeds the permitted use, you will need to obtain permission directly from the copyright holder.

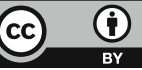

